\title{
Sosiale geregtigheid: 'n Perspektief uit die Jeremiaboek
}

W J Wessels

\begin{abstract}
Social justice: A perspective from the book of Jeremiah

The whole concem for a just society, is a major issue in the book of Jeremiah. This is expecially true as far as the kingship is concerned. Jeremiah 22:13-17 serves as an excellent example to explain the prophet's view on the current leader's role in creating and maintaining a just society. In the eyes of the prophet, king Jehoiakim has failed in this respect, whereas his father Josiah is regarded as one who has knowledge of Yahweh, reflected in his just conduct. It is clear from other sections in the book of Jeremiah, that the requirements to act justly and to reflect knowledge of Yahweh, are also expected of the members of the society. It seems that Jeremiah's view on social justice has a strong religious-ethical emphasis which distinguishes it from ordinary humanistic values.
\end{abstract}

Begrippe soos "reg en geregtigheid" het belangrike begrippe vir ons dag geraak. Vir die Christendom is die begrip "geregtigheid" 'n sleutelterm en raak dit die essensie van Christenwees. Binne Suid-Afrikaanse konteks het die begrippe "reg en geregtigheid" egter uit en uit politieke betekenis gekry en is dit eintlik 'n politieke slagspreuk waaronder elkeen verstaan wat hy of sy wil. Afhangend aan watter kant van die politieke spektrum 'n mens jou bevind, word die begrippe met inhoud gevul. Die profeet Jeremia het 'n perspektief op geregtigheid gehad wat uit dfe artikel sal blyk en wat hopelik die debat daaroor in ons dag sal stimuleer. Die kerngedeelte waaroor gehandel sal word, is Jeremia 22:13-17. Ander gedeeltes in die boek sal egter ook aan die orde kom.

Jeremia 22:13-17 vorm deel van 'n profetiese gerigsaankondiging in 22:13-19 en is in die vorm van 'n wee-uitroep. Dié uitroep word gevolg deur 'n partisipium, die aanklag asook 'n verduideliking van die aanklag'. Die gedeelte waaroor gehandel word is 'n sogenaamde Scheldrede wat met die wee-uitroep ingelei word. Die rede begin aanvanklik in die derde persoon en gaan in verse 15-17 in die direkte rede oor. Verse 18-19 wat volg, word as 'n Strafandrohung getipeer ${ }^{2}$. Die subjek van hierdie eenheid is Jojakim en die verwysing na sy vader in vers 15 is 'n verwysing na koning Josia.

By nadere beskouing van die gedeelte blyk dit duidelik dat die sleutelbegrippe waarom dit gaan, die begrippe $\mathbf{P}$ צ en bפט is. Reeds in vers 13 sê die

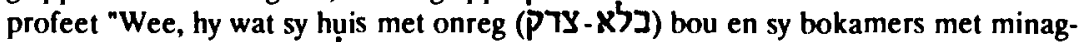

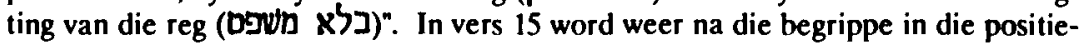
we sin verwys as Jojakim met sy pa Josia gekontrasteer word met die woorde "Maar hy (Josia) het reg laat geskied (מכ) en reg gedoen" (מקד). Voordat met die bespreking van die gedeelte voortgegaan word, volg eers ' $n$ algemene bespreking

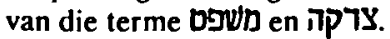


Dit is redelik duidelik dat die terme DJW en צ' ' Jeremia 22:13-19 speel. Oorsigtelik volg 'n paar menings oor die terme.

Verskeie opinies is al uitgespreek om te probeer verklaar wat צר sou beteken. Een so 'n standpunt is dat die fundamentele idee van ipר uitdrukking gee aan 'n toestand wat met 'n norm ooreenstem. Hierdie norm moet telkens in elke besondere geval opnuut gedefinieer word. צרדה is dus om aan 'n norm te konformeer ${ }^{3}$. Koch ${ }^{4}$ kritiseer die opvatting en meen dat so 'n vaste norm nie vooreksilies aan te toon is nie. Die soeke na 'n absolute norm in die Ou Testament kon nog nooit bevredigend opgelos word nie en die vraag daarna is 'n verkeerde vraagstelling'. Israel het nie 'n wyse van optrede aan 'n ideale norm gemeet nie, maar in ' $n$ bepaalde verhouding waarin die betrokke persoon staan, moet hy homself as opreg bewys.

In aansluiting by die voorafgaande haal Von $\mathrm{Rad}^{6}$ vir $\mathrm{H}$ Cremer aan wat sê "... every relationship brings with it certain claims upon conduct, and the satisfaction of these claims, which issue from the relationship and in which alone the

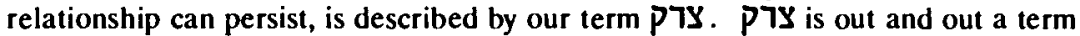
denoting relationship, and that it does this in the sense of referring to a real relationship between two parties ... and not the relationship of an object under consideration to an idea." Die opvatting dat dit oor gemeenskapsverhoudinge gaan, het by geleerdes soos Eichrodt, Kohler en Koch byval gevind?. betroubaarheid of lojaliteit beteken ${ }^{8}$.

Nog 'n poging om die begrip צרק te verstaan, is die van H H Schmid wat na analogie van oud-Oosterse ordeningsopvattings $\$$ צ' Weltordnung opvat. Die substantief צר צui oorspronklik op die kosmiese orde wat in wysheid, reg ensovoorts gekonkretiseer word en wat vanuit die aardse oogpunt deur die koning gewaarborg sal word; צרות, dienooreenkomstig, dui op optrede of handeling wat binne hierdie horison ordelik of selfs skeppend van aard is 9 . God waarborg hierdie Weltordnung en die koning is sy aardse verteenwoordiger. Elke mens moet hom hieraan oriënteer ${ }^{10}$.

Ons Westerse denke maak dit dikwels vir ons moeilik om die Israelitiese gedagtewêreld, soos in begrippe uitgedruk, te verstaan. So byvoorbeeld is dit moeilik om te verstaan dat die substantief nie slegs morele verhoudings nie, maar reeds van die begin af gesonde en heilvolle omstandighede ingesluit het ${ }^{11}$. In aansluiting hierby is in Deutero-Jesaja 'n ontwikkeling in die begrip צרד צ' bespeur in die rigting van 'n sinoniem vir heil12. Oor die algemeen dink ons in

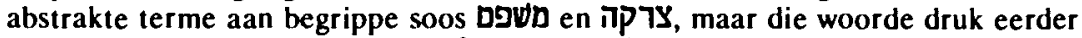
sfere waarbinne opgetree word uit ${ }^{13}$. Von Rad ${ }^{14}$ meen dat צרק צuimtelik verstaan moet word, soos 'n sfeer of 'n kragveld waarin mense ingetrek word en krag ontvang om besondere dade te verrig.

Enkele gedagtes rondom 0 UU is ook nodig. Die stam onderliggend is טDU wat die betekenismoontlikheid het "om reg te spreek". Dit behels nie alleen die uitspraak wat gelewer word nie, maar die hele gang van die regsproses 15 . Liedke 16 huldig die opvatting dat DIVD onder andere omskryf kan word as "das, was einem zukommt". Hy spreek hom verder soos volg daaroor uit: 
"Die Wendung 'das was einem zukommt' soll in erster Näherung den Charakter des משפט-Bereiches bestimmen ... Sie kann verstanden werden

- als 'das, worauf man Anspruch hat' (der Anspruch),

- als 'das, was sich für einen gehört, was sich geziemt!' (die Pflicht),

- als 'das, was für einen richtig, angemessen ist' (das Angemessene, das

Richtige),

- als 'das, was man verdient hat' (Lohn oder Strafe)."

Binne elke konteks moet bepaal word waar dit in hierdie skema inpas. Utzschneider ${ }^{17}$ meen dat 0 SW in die juridiese veld tuishoort. Die term kan ook tot die goddelike ampstoerusting van die koning (Jes 9:6) of vors (Jes 32:1b; vgl Spr 8:16) hoort. As die sterk regskonnotasie van die term op die gebiede van die uitoefening van die regering, staatsadministrasie en ordening van die staat invloed uitoefen, moet hulle aan die eis van regmatigheid onderwerp word. Jahwe se heerskappy word as 'n Rechtshemschaft beskou.

Hoewel geensins ontken word dat die terme Dפw en juridies-politieke lewe tuishoort nie, sien Vriezen ${ }^{18}$ die saak tog meer gebalanseerd as hy opmerk dat dit nie bloot 'n teoretiese of uitsluitlik forensies-juridiese betekenis het nie, maar dat dit uitdrukking gee aan die taak van die vors en die regter wat die reg moet herstel. Laasgenoemde sluit sowel hulp as oordeel in. By מפ kom die idee van 'n vasgestelde norm meer uit, maar in die aanvanklike sin handel dit eerder oor dit wat in 'n bepaalde lewensverhouding tuishoort. Om Down en IT te handhaaf, is dus om daarvoor te sorg dat regte verhoudinge bly bestaan (ספUמD) en die integriteit van elke lid van die gemeenskap volkome bly (צר).

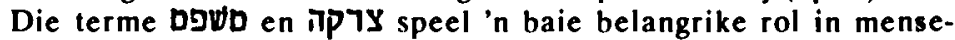
verhoudinge. Mense leef binne 'n bepaalde samelewingsorde waarbinne hulle hulself moet handhaaf. Die wysheid speel hier ' $n$ groot rol in die wyse waarop mense hul oriënteer ten opsigte van die lewe. Bogenoemde twee terme moet dus waarskynlik teen die agtergrond van die volkswysheid verstaan word.

In die wysheid word daar gesoek na die samehang in die wêreld met sy verskynsels en situasies. Daar word van die opvatting uitgegaan dat God orde in die skepping gestel het en die orde moet ontdek word. Deur intelligente waarneming en ervaring maak die wyse man sekere wysheidsuitsprake. Deist ${ }^{19}$ meen dat ' bowepersoonlike of onpersoonlike regsperspektief die wysheidsperspektief op die werklikheid as voedingsbodem het. Volgens dié regsperspektief word reg geken deur intelligente waarneming en ervaringskennis te sistematiseer. As 'n persoon die reg oortree, bring hy ongeluk oor homself en wie binne die sfeer van orde beweeg. sal voorspoed ervaar. Maar die reg het ook 'n persoonlike perspektief. Die persoonlike regsperspektief plaas alle reg onder God se gesag. Dit gaan nie meer bloot om harmonie soos by die onpersoonlike regsperspektief nie, maar om gehoorsaamheid aan 'n positiewe reg omdat God dit voorskryf. Bepaalde regsvoorskrifte moet nou nagekom word en beweeg nou op 'n etiese vlak waar 'n mens teenoor 'n medemens verantwoordelik is vir sy optrede. Die lewe word georden met voorgeskrewe reëls en mense moes hulle daarby neerlển.

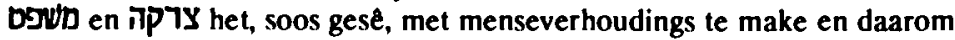
ook beide met regsperspektiewe. Uit die wysheid leer hy hoe hy hom moet 
handhaaf in 'n ordelike samelewing wat uiters noodsaaklik is vir harmonie. Soos aangetoon, meen Cremer dat die term צרקה 'n term is wat menseverhoudinge aandui en dat sulke verhoudinge sekere optredes vereis, dus kan die kennis en ervaring uit die wysheid van groot nut wees. Volgens statistiek van die gebruik van צרקה blyk dat 'n groot persentasie van die gevalle waar die term gebruik word in die wysheidsliteratuur te vind is ${ }^{21}$. Dit het reeds uit Jeremia 22:13, Spreuke 13:23 en 16:8 geblyk dat ook DSUD by die volkswysheid hoort. Vanuit 'n ander perspektief gesien, is Von Rad ${ }^{22}$ se mening dat צרק as 'n sfeer verstaan moet word waarin mense ingetrek word en sekere dade verrig, ook hier van toepassing. make met die natuurlike sfeer waarin menslike interaksie plaasvind en sekere optrede teenoor mekaar vereis word.

Samevattend: Binne gemeenskapsverhoudinge beweeg mense op 'n etiese vlak en ontstaan daar verantwoordelikheid in optrede teenoor mekaar. Uit die wysheid ontwikkel voorgeskrewe reëls waardeur lewe georden word en mense moet hulle daarby hou. 'n Persoonlike regsperspektief wat alle reg onder God stel, kom nou in die gemeenskap ter sprake 23 . Dit gaan nou nie meer bloot om harmonie nie, maar om gehoorsaamheid aan 'n persoonlike reg, omdat God dit voorskryf. Wanneer daar nou sprake is van regsvoorskrifte, word in die juridiese veld inbeweeg en kom die term Dפשמ in gedrang. DSW se betekenis moet telkens uit die konteks vasgestel word, maar dit omvat onder andere die regsproses ${ }^{24}$, die goddelike ampstoerusting van die koning, ${ }^{25}$ die orde $p$ er se $^{2 h}$. DSUb is egter ook op 'n breër veld as net die juridiese van toepasing soos uiloefening van regering, siviele administrasie en ordening van die stat ${ }^{27}$. Die term DSWD gee uitdrukking aan die taak van die vors en die regter en behels dat reg gehandhaaf moet word en hulp voorsien word 28 . צרק dui op die sfeer waarin menslike interaksie plaasvind en sekere optrede vereis word. Dit het dus ongeveer die betekenis van "lojaliteit" of "betroubaarheid" binne gemeenskapsverhoudinge. DSW het met die hele proses van die handhawing van die reg te maak, met ander woorde met orde per se. Beide terme het die wysheid as agtergrond: צרקה, die natuurlike wysheid wat berus op intelligente waarneming en ervaring en $09 \mathscr{W}$, gereglementeerde wysheid wat bepaalde riglyne neerlê vir die handhawing van goeie orde. Soms vind oorvleueling

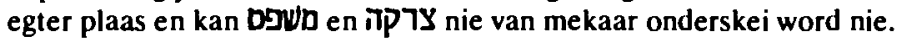

Sedert die ontstaan van die monargie het die sosiale orde die verantwoordelikheid van die koning geword en mettertyd is משט

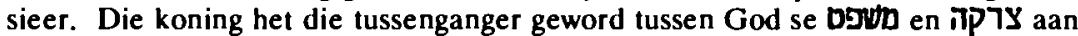
die een kant en die mens se 1 פoun an die ander kant ${ }^{29}$. Die suidelike ryk waar Jeremia as profeet optree, het waarskynlik ' $n$ wysheidsperspektief op die reg gehad. Juda het in hulle geskiedenis deurgaans internasionale kontak gehad wat 'n meer wysheidsgeoriënteerde regsperspektief vereis. Jeremia speel in op hierdie wysheidsperspektief op die reg met 'n perspektief wat trekke vertoon van Deutero-nomiese voorskrifte wat in noordelike tradisies voorkom. Dit is duidelik dat in die perikoop Jeremia 22:13-19 die terme te make het met die koning wat die sosiale orde volgens (goddelike) regsvoorskrifte moet handhaaf en sorg dat verhoudinge bevredigend gereël word. Jeremia het dus 'n religieuse perspektief op die koning wat trekke van 'n noordelike perspektief op die reg vertoon. 
Interessant in die gedeelte onder bespreking, is die vaste kombinasie waarin

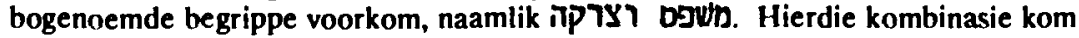
dikwels in die Ou Testament voor, naamlik agt keer in Esegiēl, ses keer in Jeremia, Jesaja vyf keer, twee keer in die Psalms en Kronieke en een keer elk in 2 Samuel, 1 Konings en Prediker. Agt van die gevalle kan as voor-eksilies gedateer word ${ }^{30}$ en sewentien gevalle eksilies/na-eksilies ${ }^{31}$.

'n Belangrike waarneming wat uit die gegewens blyk, is die feit dat die gebruik van die kombinasie in twaalf van die gevalle te make het met die wyse hoe 'n koning regeer of behoort te regeer. Ses van die betrokke gevalle kan vooreksilies gedateer word en dui daarop dat dié kombinasie reeds voor en gedurende die profeet Jeremia se tyd in kontekste wat handel oor die wyse hoe konings regeer, gebruik is. Dit is duidelik dat die terme ip koningskap. Jeremia sluit waarskynlik in Jeremia 22:15 by 2 Samuel 8:15 en 1 Konings 10:9 aan waar dit handel oor die geïdealiseerde konings Dawid en Salomo se wyse van regeer wat dien as maatstaf vir ander konings. Dit blyk verder dat Jeremia 22:3; 23:5 en 33:15 wat betref die verwysing na geregtigheid, uit Jeremia 22:15 voortvloei. Interessant is ook die feit dat ses van die gevalle waar die woordkombinasie oor reg en geregtigheid met betrekking tot koningskap voorkom, na-eksilies te dateer is. Waarskynlik is die rede daarvoor dat, hoewel daar nie meer 'n fisiese koning op die troon was nie, die ideaal bly voortleef het dat dié soort optrede in 'n toekomstige koning sal realiseer. Dit is ook belangrik om daarop te let dat hierdie wyse van optrede in die eksilies/na-eksiliese tyd ook as korrekte wyse van lewe vir die individu voorgehou word.

Konkrete inhoud aan die onreg of gebrek aan reg by Jojakim word in die gedeelte gegee met die kontrastering met Josia (verse 15-16) en die uitspel van sy

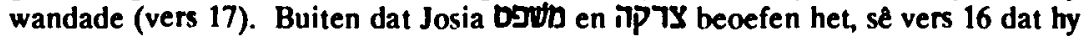
die saak behartig het van die swakke (ענכי) (בירן) en die arme. Die vaste uitdrukking עני ואבירן kom verskeie plekke in die Ou Testament in verskillende kontekste voor. In 'n reeks tekste word opdrag gegee hoe om teenoor hierdie kategorie mense op te tree ${ }^{32}$, beskuldiging van verkeerde optrede teenoor hulle ${ }^{33}$, 'n toestand beskryf as swak en arm ${ }^{34}$, beskrywing van positiewe optrede teenoor die swakkes en armes 35 , asook negatiewe optrede 36 .

Dit wil voorkom of die kombinasie van die twee terme dikwels ' $n$ vaste uitdrukking gevorm het. Die oudste gebruik kom uit Deuteronomium 15:11 en 24:14 wat deel vorm van die Deuteronomiese wet in Deuteronomium 12-26 en dus uit die oorspronklike boek van Deuteronomium ${ }^{37}$. In Deuteronomium 15:11 handel dit oor die arm broer of volksgenoot wat in sy materiěle nood bygestaan moet word en in 24:14 handel dit oor die dagloner wat regverdig behandel moet word. Indien Deuteronomium noordryks van oorsprong is en Jeremia in die tradisie staan - ' aanname waarvoor daar goeie grond is - moet Jeremia se gebruik van die terme binne die konteks van dié betekenisveld van עני ואביון verstaan word. Dit is ook duidelik dat Spreuke 31:9 nou verwant is aan Jeremia 22:16, want in albei gevalle gaan dit om die koning wat na die regsaak van die עני ואביון moet omsien. Spreuke 31:1-9 is waarskynlik 'n voor-eksiliese redaksionele byvoeging 38 en Steck ${ }^{39}$ verwys daarna as 'n "nichtisraelitischer Anhang". Dit gaan hier om die onderrig van' $n$ moeder aan haar seun en lé dus op die vlak van praktiese 
lewenswysheid. Soos by 22:13 aangedui, put Jeremia uit die volkswysheid in sy

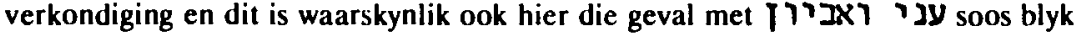
uit die verwantskap met Spreuke 31:1-9. Dit is duidelik dat Jeremia met die Deuteronomiese tradisie in aanraking was. Ily het waarskynlik daarmee in aanraking gekom weens die feit dat die plattelandse priesters en leviete die Deuteronomiese tradisie voortgedra het en Jeremia in die priesterstad Anatot daarmee kennis gemaak het ${ }^{40}$, of ' $n$ ander moontlikheid is dat Jeremia deur sy noue verbintenis met die tempel waar hy opgetree het en deur sy kontak met Safan en sy familie, met die wetboek wat in Josia se tyd gevind is, in aanraking was. Jeremia het egter soos geblyk het, ook die volkswysheid benut vir sy verkondiging en daarom kan veronderstel word dat die gebruik van 5 in 22:16 Jeremiaans is.

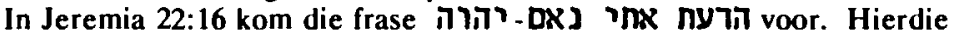
frase kom oorwegend in die boeke Jeremia en Hosea voor. Soms word dit in kontekste wat gerig aankondig gebruik ${ }^{41}$, maar soms ook wanneer uitdrukking aan heil gegee word ${ }^{42}$. 'n Paar ander gebruike kom ook voor ${ }^{43}$. Buiten die gebruike in Jesaja en Daniël, is al die ander gevalle voor-eksilies te dateer ${ }^{44}$. Die feit dat daar 'n duidelike verwantskap bestaan tussen die noordrykse Hosea en Jeremia ${ }^{45}$ is waarskynlik toe te skryf aan die feit dat hulle 'n gemeenskaplike tradisie gedeel het (waaraan Oerdeuteronomium moontlik uitdrukking gee) en die gebruik van $n y$ in Jeremia 22:16 moet teen dié agtergrond verstaan word. In meerdere gevalle blyk dit dat Jeremia deur noordrykse tradisies beïnvloed is, soos ook uit vers 17 sal blyk.

In vers 17 volg 'n reeks werkwoorde en uitdrukkings om die verkeerde optrede van Jojakim nog duideliker te stel. Hy word daarvan beskuldig dat sy oog en hart op niks anders is as onregverdige wins (עצב), om onskuldige mense dood te

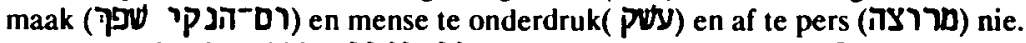

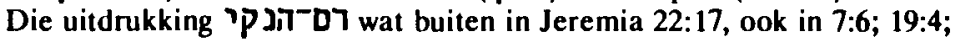
$22: 3$ en $26: 15$ voorkom, word ook in Oerdeuteronomium $(19: 10,13 ; 21: 8,9)$ en in sogenaamde Deuteronomistiese gedeeltes (Dt 27:25, 1 Sm 19:5, 2 Kn 21:16; 24:4) gebruik $^{46}$. Hoewel sommige ${ }^{47}$ Jeremia 7:6 en 19:4 aan die Deuteronomis toeskryf, is daar geen oortuigende rede om 22:17 aan Jeremia te ontsê nie. Waarskynlik dui dit eerder daarop dat die profeet se woordgebruik en gedagtegang by dié van die Deuteronomies-Deuteronomistiese beweging aansluit.

1.2.1 Jeremia 22:13-17 moet teen die agtergrond van die internasionale politiek verstaan word. Koning Josia het in 'n veldslag teen Egipte gesneuwel en sy seun Joahas het in sy plek koning geword. Na slegs drie maande se bewind is hy egter onttroon en na Egipte toe weggevoer. In sy plek het Eljakim (Jojakim) as 'n vasal van Egipte sy plek op die troon ingeneem. Dit het beteken dat hy 'n swaar tribuut

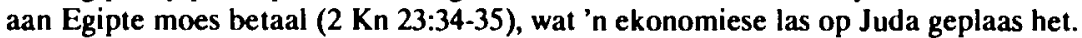
Om sy skuldlas teenoor sy oorheerser te kon dra het Jojakim swaar belasting van sy

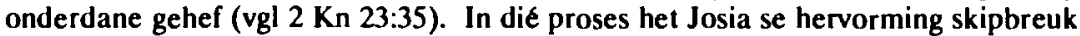
gelei en heidense gebruike is weer ingevoer. Dit het teenkanting van sommige profete ontlok waaronder ook Jeremia, met noodlottige gevolge vir party van hulle (vgl Jr 26:20-23).

Jeremia spreek in Jeremia 22:13-17, wat met 'n wee-roep begin, sy misnoeë uit oor Jojakim se optrede. As toonbeeld van sy selfgesentreerdheid en grootheidswaan, het die koning vir hom 'n swierpaleis gebou. Deur sy bouprojekte wou hy met ander konings wedywer en hulle oortref in weelde. Dit ontlok die 
hewige kritiek wat in Jeremia 22:13-19 aangetref word. Die hele wese van sy koningskap word deur die kritiek van die profeet ontbloot.

Op subtiele wyse toon Jeremia aan dat die bouprojekte die uitvlocisel is van 'n verkeerde koningsopvatting. Koning Jojakim is wel besig met bouwerke, maar eintlik bou hy met ongeregtigheid en onreg. Sy bouwerk is tiperend van die feit dat gesonde menseverhoudings nie tot hulle reg kom nie en dat hy die reg van andere minag. Hy betaal nie sy werkers hulle verdiende loon nie en in 'n ekonomies moeilike tyd is hy besig om homself te verryk. Soos 'n Egiptiese despoot breek hy vir hom 'n "verskyningsvenster" uit vanwaar hy hom by onthale of met toesprake $\operatorname{soos}^{\prime} n$ farao kon vertoon ${ }^{48}$. Op sigself is hierdie klagtes teen 'n koning nie vreemd nie. Salomo is 'n goeie voorbeeld van 'n koning wat koningskap in terme van massiewe bouprojekte gemeet het. Om hierdie simbole van selfverheerliking te kon oprig, het hy mense onderdruk en swaar belastings opgele 49 . Die soort kritiek vind ons dikwels in die Bybelse tradisies wat oor die monargie handel (vgl $1 \mathrm{Sm} \mathrm{8-12),}$ terug ${ }^{50}$. Hierdie optredes is ook vir Jeremia uitvloeisels van 'n wesenlike verkeerde opvatting by Jojakim oor hoe koningskap daar behoort uit te sien. Wat wesentlik verkeerd is, spel Jeremia uit deur Jojakim te kontrasteer met sy vader Josia (vers 15). Deur die effektiewe gebruikmaking van retoriese vrae laat die profeet duidelik blyk hoe 'n goeie koning behoort te regeer. Josia was vir Jeremia so 'n model. Wat die verhouding tussen Jeremia en Josia betref, is dit heel duidelik dat hy hom, net soos die Deuteronomistiese redaksie van 2 Konings 22:2, positief beoordeel het. Josia het as koning stylvol geleef, hy het geëet en gedrink, maar stylvolheid is nie waarin sy koningskap bestaan het nie. Soos dit 'n verstandige koning betaam, het hy reg en geregtigheid beoefen. Hy het, volgens Jeremia, dus toegesien dat die sosiale klimaat ideaal is, sodat mense in gesonde verhoudinge met mekaar kon lewe (ipרצ) en dat aan die eise vir die korrekte optrede binne die gemeenskap voldoen sou word (OSWD). Hy het ook die regsaak van die sosiaal-swakkes behartig (I 7

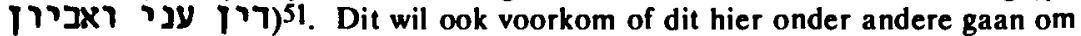
persone wat materiële probleme ondervind het en na wie se regsaak die koning moes omsien. Die waarskynlikheid is groot dat die verwysing in vers 16 a ook 'n wyer sosiale betekenis in Jojakim se tyd kon he, veral as Jeremia 9:2-6 vergelyk word waar gese word hoe min ip 7 daar was. In vroeëre navorsing is die opinie gehuldig dat die idee van die beskerming van die geringes, die armes, weduwees en wese, tipies was van en beperk was tot die Israelitiese Godsreg. Soorgelyke tendense is egter gevind in Sumeriese, Akkadiese en Ugaritiese literatuur, sodat die beskerming van die swakkes dus nie eksklusief Israelities was nie 52 . Dit is verder as 'n deug van 'n koning beskou as hy die reg van die swakkes (armes, ellendiges, weduwees en wese) van die samelewing sou beskerm. In Israel is die koning as God se verteenwoordiger beskou en omdat dit die wil van God was dat die swakkes beskerming moes geniet, was dit die taak van die koning om dit in die praktyk toe te pas 53 . Deurdat Josia al hierdie verpligtinge nagekom het in sy regering, kon Jeremia 'n waardeoordeel uitspreek: Josia was 'n suksesvolle koning. Sy optrede het lewensmoontlikhede ontsluit in kontras met Jojakim, wat deur sy optrede lewensmoontlikhede beperk of vernietig het. Jeremia meen dat regverdige optrede 'n weerspieëling is van ware kennis van Jahwe (רוה יהוה). Laasgenoemde uitdrukking dui nie op kennis van Jahwe se wese nie, met ander woorde, dit is nie 'n ontologiese uitspraak nie, maar wel om in die regte verhouding met Hom te lewe ${ }^{54}$. Om Jahwe te ken, beteken om in 'n verhouding van vertroue en gehoorsaamheid 
met Hom te leef en om ervaring van Hom te hê55. Dié kennis kan verkry word deur waarneming, ervaring en bewuswording en kan geleer en oorgedra word ${ }^{56}$. Dit is nie moontlik om die verbond as agtergrond vir רער מה 22:16 te sien soos dit dikwels by Hosea die geval is nie (vgl Hos 2:18-22; 6:5-7; 8:1-3), hoewel dit in 31:34 wel die geval is. Dit is eerder die "priester" Jeremia wat hier aan die woord is en teen die agtergrond van die wet van Jahwe, Israel se heilshistoriese tradisies en sy lewenservaring sê wat Jahwe vereis ${ }^{57}$. In die konteks waarin 22:16 voorkom, blyk dit dat om Jahwe te "ken", beteken om sosiaal korrek te leef, sodat alle lae van die bevolking goeie lewensomstandighede kan geniet. Jeremia sê dat verstandige en regverdige optrede 'n weerspieëling is dat 'n persoon Jahwe ken en dit kan nie van Jojakim gesê word nie.

Nadat die profeet die goeie optrede van Josia geskets het, begin hy met die opnoem van die dinge waaraan Jojakim hom skuldig gemaak het (vers 17). Die kontras is geweldig, want Jeremia noem uitbuiting, bloedvergieting, verdrukking en afpersing as verkeerde elemente in die uitoefening van Jojakim se koningskap. Jojakim tree dus op soos 'n tipiese despoot wat ander misbruik vir eie gewin. 'n Voorbeeld van die feit dat Jojakim hom wel op 'n keer aan bloedvergieting skuldig gemaak het, word gereflekteer in Jeremia 26:20-23 waarvolgens hy die profeet Uria laat vermoor het. Vers 17 toon baie duidelik waarom die profeet sy rede in vers 13 met die הר ingelei het: Hy kan nie sterk genoeg aan sy misnoeë uitdrukking gee nie, want hy keer die koning se optrede radikaal af.

Soos reeds aangedui, blyk uit Jojakim se optrede dat sy koningsopvatting strydig was met die opvatting wat Jeremia daaroor gehad het. Die kritiek wat Jeremia teen Jojakim se bouprogram uitspreek, moet nie verstaan word as kritiek teen bouwerke as sodanig nie - dan sou Salomo ook "skuldig" wees aan dié "misdryf" - maar as kritiek teen Jojakim se regeringstyl: die aard van die bouwerke illustreer sy gesindheid en siening van die koningskap: valse sekuriteit, onreg, bedrog, moord, verdrukking en afpersing. Jojakim se koningsopvatting het sekerlik voortgespruit uit, of aangesluit by die opvatting wat in die suidelike ryk oor die instelling gehuldig is. Die beskouing dat die belofte aan Dawid 'n ewige, onvoorwaardelike dinastie gewaarborg het, het aanleiding gegee tot 'n gevoel van sekuriteit: "Jahwe is in hulle midde, Hy woon op Sion, die tempel staan en daar is ' $n$ koning uit Dawid se geslag op die troon". Hierdie simbole het as waarborg gedien vir die oninneembaarheid van Jerusalem en die permanensie van die koning. Jojakim se luukse boubedrywighede moet juis teen die agtergrond van hierdie oortuiging gesien word: Ten spyte van politieke woelinge op internasionale vlak, is Jojakim besig met luukse bouprojekte.

In die gang van die geskiedenis was dit vreemd dat Sallum vór Jojakim op die troon was, want volgens die normale prosedure moes Jojakim regeer het. Dit moes vir die ondersteuners van die anti-Josiagroep 58 van die bevolking groot tevredenheid en gerustheid verskaf het toe die "ware opvolger" eindelik die troon van Dawid bestyg het. Jojakim het afgewyk van sy vader Josia en sy broer Joahas (Sallum) se regeenwyse. Jeremia wys duidelik waar sy simpatie lè deur koning Josia as model vir Jojakim voor te hou en hulle te kontrasteer. Deur na Josia te verwys, beklemtoon Jeremia eintlik die saak waarom dit gaan: ware geregtigheid. In dié opsig sluit Jeremia sterk aan by die koningswet in Deuteronomium 17:14-20 en dus by die noordrykse koningsopvatting. Dit was die plig van die koning om om te sien na die sosiale swakkes en om sosiale orde te handhaaf. As vasal van God moes hy 
kennis (ny7) van Jahwe hê en dit prakties sighaar maak deur die wyse waarop hy regeer het. Jojakim, wat Jahwe moes verteenwordig, het misluk en was vir Jeremia die simbool van 'n mislukte koningskap, ten minste wat die koningsideologie van die suidelike ryk betref.

Daar is goeie grond om aan te neem dat Jeremia, wat sy koningsopvatting betref, in die noordrykse tradisie staan: Die koning moes steeds in verantwoordelikheid teenoor God regeer en sy vereistes nakom. Soos die gebruik van sekere begrippe getoon het, sluit Jeremia as priester by Deuteronomium aan en indien laasgenoemde noordryks van norsprong is, is dit te begrype waarom Jeremia se gebruik van die begrippe in die sfeer te verstaan is. Dit het egter ook duidelik geword dat Jeremia aansluiting vind by die praktiese lewenswysheid van die volkswysheid. Jeremia se koningsopvatting is dus ook gevorm deur die gewone volkswysheid se aanvoeling vir billikheid en reg. Wanneer hy dus begrlppe soos 17 gebruik, moet dit verstaan word teen die agtergrond van 'n werklikheid waarin noordrykse tradisies en gewone volkswysheid 'n beduidende rol speel. Vanuit sy koningsopvatting, wat berus het op geregtigheid soos hy dit vanuit sy agtergrond (Deuteronomies en praktiese lewenswysheid van die volkswysheid) verstaan het - het Jeremia die suidelike koningskap, soos getipeer deur Jojakim, as 'n valse ideologie beskou. Die onvoorwaardelikheid en ewigheid van die suidelike koningsopvatting het valse sekuriteit en misvormde sosiale verhoudings in die hand gewerk.

Sosiale geregtigheid in die boek Jeremia

Nadat daar in meer detail gekyk is na die opvatting oor reg en geregtigheid in Jeremia 22:13-17, moet enkele ander perikope in die boek Jeremia oor die aangeleentheid, ook onder oë geneem word.

2.1 Jeremia 2:32-37: Hierdie gedeelte uit die tyd van Josia59, gebruik die beeld van Israel as bruid wat in 'n verbondsverhouding met Jahwe staan. Israel het egter in ontrouheid liefde op 'n ander plek gaan soek (waarskynlik die Ballkultus) 60 , hulle verhouding met Jahwe verbreek en 'n verkeerde lewenstyl begin handhaaf. Vers 24 verwys na die feit dat hulle onskuldige bloed vergiet het (vgl Jr 22:17) en dan ontken Israel nog dat hulle mense onderdruk, uitbuit en moor. Jeremia kritiseer hierdie ontrouheid aan Jahwe as die oorsaak vir die verkeerde leefwyse wat hulle handhaaf.

2.2 Jeremia 5:1-6: Hoofstuk 5 verskaf die redes vir Jahwe se oordeel wat in hoofstuk 4 aangekondig is ${ }^{61}$ en dateer ook uit Josia se tyd ${ }^{62}$. In die gedeelte gaan dit om 'n uitnodiging om in die strate van Jerusalem en by die handelspleine te gaan

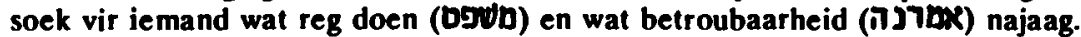
Jahwe is bereid om sy oordeel op te hef en sy volk te vergewe indien daar die sulkes gevind word. As verskoning vir die feit dat die mense verkeerd bly handel, voer Jeremia aan dat dit die gewone mense is (handelaars, handewerkers ens) ${ }^{63}$ is wat die Godsreg nie ken nie en uit onkunde ander benadeel. Hy sal na die leiers in die samelewing gaan (waarskynlik die profete, priesters en die volksleiers) ${ }^{64}$ wat wel weet wat die wil van Jahwe is en hoe om reg op te tree (OSWD). osth het in die verband met die korrekte etiese optrede te make en verwys nie na kultiese optrede 
nie $^{65}$. Die profeet se ontnugtering is egter groot, want die sogenaamde "grotes" onder die volk is rebels en wil onder die juk van hulle heer uitkom en hulle eie gang gaan (vers 6). Die gevolg is dat straf nie kan uitbly nie. Die feit dat daar so 'n gebrek aan kennis van die Godsreg was en dit terwyl Josia besig was met sy hervormingsprogram, moes des te meer bygedra het tot die profeet se ontnugtering. Thompson ${ }^{66}$ meen dat die klem hier op die sosiale en persoonlike moraliteit val en dat hoofstuk 5 in 'n fase ná die hervorming van Josia val. Die hervorming was waarskynlik meer suksesvol met betrekking tot die vernietiging van kultiese aanbiddingsplekke en uiterlike steurnisse.

2.3 Jeremia 5:26-29: In hierdie gedeelte wat waarskynlik dateer uit die laaste jare van Josia se regering of vroeg in Jojakim se tyd, ${ }^{67}$ spreek Jeremia hom uit teen 'n groep mense wat waarskynlik welvarend was en beide die status en posisie gehad het om die sosiaal swakkes (armes en wese) van hulp te wees. Soos voëlvangers het hulle hierdie swakkes in hulle mag gekry en van hulle vryheid beroof. Vers 29 impliseer dat Jahwe hulle sal straf en Hom op hulle sal wreek. Jeremia verwag van mense van posisie (hierby word die koning ook gereken) om toe te sien dat reg aan dié mense in die gemeenskap geskied.

2.4 Jeremia 6:1-8: In hierdie perikoop, wat uit verse $1-5$ en $6-8$ bestaan, is laasgenoemde verse van belang vir die tema van sosiale reg. 'n Vyand uit die noorde wat Jahwe se opdrag van oordeel uitvoer, bedreig in Josia se tyd ${ }^{68}$ die inwoners van Jerusalem. In die stad heers toestande van geweld en onreg, mense word geweld aangedoen en mishandel. Ten spyte van Josia se hervormings en pogings om toe te sien dat reg geskied, heers daar tog wantoestande. Die profeet kondig gevolglik oordeel aan.

2.5 Jeremia 8:4-7: Sommige geleerdes meen dat dié gedeelte net so goed in Josia as Jojakim se tyd sou pas 69 . Jeremia mak van voorbeelde gebruik om sy punt tuis te bring. In vers 4 is praktiese voorbeelde uit die alledaagse lewe: Sal iemand val en nie weer opstaan nie? Of sal iemand weggaan en nie weer terugkom nie? Hierdeur gee die profeet uitdrukking aan sy onbegrip dat Juda so dwaas kon wees om te weier om na Jahwe toe terug te keer. Hulle volhard met 'n afkerige houding en pleeg bedrog, hoewel hulle weet dat hulle op die verkeerde pad is. Daar is nie sprake van berou nie ${ }^{70}$. In vers 7 maak Jeremia van ' $n$ wysheidsbeeld uit die natuur gebruik en toon aan dat elke dier sy plek en roetine het en stiptelik by dié orde van Jahwe hou. Die volk van Jahwe ken egter nie die regsorde (DJVD) van Jahwe nie. Israel wil niks van die etiese voorskrifte van Jahwe weet nie. Jeremia wou toon dat die vereistes van Jahwe natuurlike kennis en optrede by die volk moes veronderstel soos die geval by die natuur, maar die teendeel was waar. Jeremia impliseer dat eties-korrekte optrede by die volk iets naturliks behoort te wees. Uit 'n wysheidsperspektief sou hulle as "dwase" bestempel kon word.

2.6 Jeremia 9:1-8: Hierdie gedeelte is 'n klaaglied oor die verdorwe toestand van die volk ${ }^{71}$ gedurende die regeringstyd van koning Jojakim. Die eerste vier verse bevat die klag, waarop die antwoord van Jahwe in verse $5-8$ volg 72 . Die volk se ontrouheid het bestaan uit leuens, bedrog, onderkruipery, kwaadstook en verdrukking. Uitbuitery en wantroue bestaan onder familie en vriende. Twee keer (verse 3

ISSN 0257-8891 = SKRIF EN KERK Jrg 13 (1) 1992 
en 5) word herhaal dat die volk die weg van Jahwe nie ken nie. "Ken" (ע/') moet nie slegs verstaan word as ' $n$ verwysing na intellektuele kennis nie, maar kennis wat voortvloei uit 'n noue verhouding tussen Jahwe en 'n individu ${ }^{73}$. Die oorsprong van die ontrou en onreg is vir Jeremia geleë in die gebrekkige verhouding tussen die volk en Jahwe. Vir hierdie ontrouheid sal Jahwe hulle straf en deur 'n smeltkroes laat gaan. Jeremia beween die toestand van sosiale onreg wat onder sy volksgenote bestaan.

2.7 Jeremia 9:22-23: Dié gedeelte handel oor ware roem. Die mens moet nie roem in sy eie wysheid en in sy welvarendheid nie, maar dat hy insig in die lewe het en Jahwe ken (vgl $2: 8 ; 4: 22 ; 9: 2,5$ en $22: 16$ ). Hierdie kennis word geleer vanuit 'n noue verwantskap met Hom. Thompson 74 meen dat die funksie van die gedeelte in hoofstuk 9 is om vir die volk aan te dui dat hulle enigste hoop in hulle gesketste negatiewe omstandighede, geleë is in Jahwe se getrouheid, sy regte optrede en regverdigheid. Jahwe verwag sulke optrede van mense met ware kennis ${ }^{75}$. Sosiale verhoudings gebou op dié basis moet gekenmerk word deur liefde, reg en geregtigheid. Kennis van Jahwe by Jeremia is dus nie bloot 'n teoretiese aangeleentheid nie.

2.8 Jeremia 17:11: In nog 'n gedeelte uit Jojakim se tyd, 76 het Jeremia dit oor rykdom wat onreguerdig bekom is en 'n sosiale onreg veroorsaak. Hierdie vers is 'n voorbeeld van lewenswysheid wat spruit uit 'n fyn waarneming van die dierewereld deur die profeet. 'n Fisant wat 'n vreemde eier uitbroei, behou nie die kuiken nie. In 'n stadium volg die kuiken sy aangebore natuur en laat die fisant agter 77 . Rykdom wat onregverdig bekom is, sal spoedig verlore gaan en die persoon sal as 'n dwaas getipeer word. In die geval sluit Jeremia in sy opvatting oor sosiale geregtigheid, net soos by 2.5 die geval was, by lewenswysheid wat uit die praktyk verkry is aan.

2.9 Voorlopige samevatting: Wit die bespreking van die gedeeltes onder hierdie tweede punt, is dit duidelik dat die aangeleentheid van sosiale geregtigheid vir Jeremia 'n belangrike saak is. Verskeie redes daarvoor word as oorsaak aangevoer. Israel handel ontrou deur vreemde gode aan te hang. Gebrek aan kennis van die Godsreg lei tot verkeerde optrede en tot benadeling van die medemens en God se oordeel. Die profeet stel in geen onduidelike taal wat die onreg is wat gepleeg word en waardeur die swakkes in die samelewing benadeel word nie. Vir Jeremia is die bron van die onreg geleë in 'n gebrekkige kennis van Jahwe. Deur hulle verhouding met Hom te herstel en Hom te dien, sal hulle leer wat ware kennis van Jahwe is, naamlik liefde, reg en geregtigheid. Laasgenoemde eienskappe is die riglyne vir geordende samelewingsomstandighede en die leiers van die volk (in besonder die koning) moet toesien dat dit realiseer (vgl 5:5,27; 6:22; 22:15,16).

Jeremia se siening van die reg sluit enersyds by die Godsreg aan (wat op 'n persoonlike regsopvatting berus en dus aan God ondergeskik is), maar andersyds ook by die praktiese lewenswysheid (wat 'n bo-persoonlike regsopvatting impliseer en op ervaring en fyn waarneming berus - vergelyk die bespreking oor b משט กิРY). 
Die bespreking van Jeremia 22:13-17 het getoon dat die profeet hom sterk uitgespreek het teen die wyse van optrede van koning Jojakim. Terwyl 'n mens begryp dat dit kritiek was wat geloods was teen 'n koning wat in bepaalde sosio-historiese omstandighede opgetree het, sal dit seker geregverdig wees om hieruit sekere afleidings oor leierskap in die algemeen te maak. 'n Leier moet sekere waarborge en standaarde stel in 'n gemeenskap om dit ' $n$ gemeenskap te maak waar regverdigheid hooggeag en eerbiedig word. Van die verwagtinge sou onder andere wees dat:

3.1 Die leier self regverdig moet optree

3.2 'n Leier eie voordele en ideale ondergeskik moet stel aan die taak as leier

3.3 'n Leier moet toesien dat 'n klimaat in die samelewing geskep word sodat reg toegepas kan word

3.4 Die regte en posisie van die "swakkes" in die samelewing beskerm moet word

3.5 Die waarde en behoud van lewe hoog aangeslaan moet word

3.6 Die vryheid van mense hooggeag en onderdrukking teëgewerk moet word

3.7 Lewensmoontlikhede vir mense ontsluit eerder as beperk moet word.

Kyk ' $n$ mens vanuit jou eie samelewingsopset, sou mens kon sê dat dit alleen billik sou wees om sulke verwagtinge aan leierskap te stel. Dit is heeltemal te versoen met humanistiese ideale. Dit hoort so. Vanuit 'n godsdienstige oogpunt gesien is daar egter 'n etiese eis wat gestel word. יהרה vereis, ook gesien in die lig van die voorafgaande bespreking, 'n sekere optrede wat sou weerspieël dat so 'n persoon God ken. Omdat יהוה se koningskap erken word en 'n gelowige leier in 'n verhouding met Hom staan, kan sekere etiese optrede verwag word. Die Profeet noem dit רעת יהור (kennis van Jahwe).

Jeremia as profeet van Jahwe werk vanuit 'n bepaalde godsdienstig-etiese oortuiging en daaraan beoordeel hy die samelewing, die mense in die samelewing en die leierskap. Sy meer noordrykse koningsopvatting waarin Jahwe as heerser gesien word en die koning sy verteenwoordiger op aarde, voorsien die raamwerk van sy beoordeling en verwagting. Terwyl die leierskap primêr aanspreeklik is vir die handhawing van sosiale geregtigheid en 'n klimaat waarbinne korrekte en billike optrede kan plaasvind, is elke lid in die samelewing mede-verantwoordelik dat dit tot stand kom. Vanuit 'n godsdienstige perspektief kom die eis van eties korrekte optrede wat spruit uit 'n aanspraak van יהיה op so 'n persoon se lewe en kennis van die verwagte optrede wat Hy stel. Hierdie kennis moet prakties in die samelewing neerslag vind in regte en regverdige optrede.

Op ons wat daarop aanspraak maak dat ons in 'n lewende verhouding met יהוה leef, rus die verantwoordelikheid om die kennis van God se reg daagliks uit te leef. In 'n verskeurde samelewing soos ons s'n waar verdeeldheid heers en 'n ernstige behoefte is na ware sosiale geregtigheid, kan die gelowige met sy kennis van die Here, helend en rigtinggewend optree. Indien die leiers van die land dit nie doen nie, dan moet die lede van die samelewing reg optree soos God dit vereis en hulle moet die eis aan die leiers van die dag stel vir sodanige optrede. 


\section{NOTAS}

1 C Westermann, Grundformen prophetischer Rede, München 1964, 139.

2 W Rudolph, Jeremia, Tühingen 1968, 139.

3 E Jacob, Theology of the Old Testament, I ondon 1974, 94.

$4 \mathrm{~K}$ Koch, "SDQ", in E Jenni \& C Westermann (eds), THAT, Münehen 1976, 515.

5 G von Rad, Old Testament Theology vol 1, Norwich 1975, 371.

6 Von Rad, $a w, 371$.

$7 \quad$ Koch, $a w, 515$.

8 F E Deist, "Aantekeninge by Gen 15:1,6", NGTT vol 12 (1971), 100-102.

9 H H Schmid, Gerechtigkeit als Weltordnung, Tübingen 1968, 67.

10 Koch, $a w, 516$.

11 Koch, $a w, 515$.

12 Von Rad, $a w, 372$.

13 K Koch, The prophets: The Assyrian period, Philadelphia 1983, 60.

14 Von Rad, $a w, 376$.

15 Jacob, $a w, 97$.

16 G Liedke, Gestalt und Bezeichnung alttestamentlicher Rechtssätze, Neukirchen 1971,78 .

17 H Utzschneider, Hosea, Prophet vor dem Ende. Freiburg 1980, 154.

18. Th C Vriezen, Hoofdlijnen der theologie van het Oude Testament, Wageningen 1974, 421.

19 F E Deist, Texts with a legal perspective" in F E Deist en W S Vorster (eds), Words from afar, Cape Town 1986, 187-189.

20 Deist, $a w, 189-193$.

21 Koch, $a w, 511$.

22 Von Rad, $a$ w, 376.

23 Deist, $a w, 187-189$.

24 Jacob, $a w, 97$. 
25 Utzschneider, $a w, 154$.

26 Koch, a w, 1983, 59.

27 Utzschneider, $a w, 154$.

28 Vriezen, $a w, 421$.

29 Koch, a w, 1983, 60.

302 Samuel 8:15, 1 Konings 10:9, Jeremia 4:2; 9:23; 22:15; 23:5; 33:15, en Psalm 99:4; vgl G Fohrer, Einleitung in das Alte Testament, Heidelberg 1969, 239239, 250-251, 431-439; Rudolph, a w, 69; H-J Kraus, Psalmen 1-63, Neukirchen 1972, 683.

$31 \quad 1$ Kronieke 18:14, 2 Kronieke 9:8, Jesaja 1:21; 9:6; 16:5; 33:5; 56:1, Jeremia 22:3, Esegiël 18:5, 19, 21, 27; 33:14, 15, 19; 45:9, Prediker 5:7; vgl Fohrer, $a w$. 400-421, 447-455, 314-316.

32 Deuteronomium 15:11; 24:14, Spreuke 31:9.

33 Esegiël 16:49; 18:12; 22:29 en Psalm 1(09:16.

34 Psalm 40:18; 70:6; 86:1; 104:22.

35 Psalm 35:10; 41:17; 72:12; 140:13, Jesaja 41:17, Jeremia 22:16.

36 Job 24:14, Psalm 37:14.

37 A D H Mayes, The story of Israel between settlement and exile, London 1983, 22,38 .

38 Fohrer, $a w, 352$.

39 O H Steck, Arbeitsblätter Altes Testaments für Einfühnungskurse, Zürich 1982, 16.

40 G von Rad, Deuteronomy, London 1974, 24-25.

41 Hosea 4:1,6; 5:4; 8:2, Jeremia 2:8, 4:22 en 9:2,5.

42 Hosea 2:22, Jesaja 11:2,9, Jeremia 24:7; 31:34.

43 Hosea 6:3,6; 13:4, Daniël 11:32 en Jeremia 22:16.

44 C van Leeuwen, Hosea, Nijkerk 1968, 71-72, 95, 119, 136, 141, 254.

45 A Deissler, "Das 'Echo' der Hosea-Verkündigung im Jeremiabuch", in L Ruppert, P Weimar \& E Zenger (Hrsg), Künder des Wortes, Würzburg 1982, 61-75.

46 Mayes, $a w, 54,134$; vergelyk ook $\mathrm{H}$ Weippert, "Die 'deuteronomis tischen' Beurteilungen der Könige von Israel und Juda und das Problem der 
Redaktion der Königshïcher", Bih vol 53 (1972), 301-339.

47 Rudolph, $a w, 53,127,171$.

48 J A Thompson, The hook of Jeremiah, Grand Rapids 1980, 478; Rudolph, a $w, 139$.

49 R P Carroll, From chans to covenant, London 1981, 143; vgl ook W McKane, Jeremiah I-XXV, Edinburgh 1986,527-528.

50 H Schüngel-Straumann, "Kritik am Königtum im Alten Testament", BiKi vol 12 (1981), 197-200.

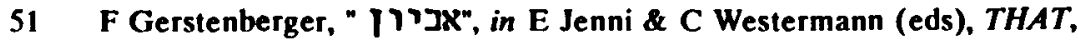
München 1971, 23.

52 F C Fensham, "Widow, orphan, and the poor in ancient Near Eastern legal and wisdom literature", JNES vol 21 (1962), 134,137.

53 H Wildberger, Jesaja 1-12, Neukirchen 1972, 48; Fensham, $a w, 138$.

$54 \quad$ Vriezen, $a w, 169$.

55 H W Wolff, Dodekapropheten 1. Hosea, Neukirchen 1965, 153.

56 W Schottroff, "jo c", in E Jenni \& C Westermann, THAT, München 1971, 687.

57 Schottroff, $a w, 696$.

58 Thompson, $a w, 476$. Hy wys op interne politieke konflik en groepvorming.

59 Rudolph, $a w, 13$.

60 J Schreiner, Jeremia 1-25, Würtzburg 1981, 24; R E Clemens, Jeremiah, Atlanta 1988, 28-30.

61 P Volz, Der Prophet Jeremia. Hildesheim 1983 (1928), 60; B J Oosterhoff, Jeremia I-10, Kampen 1990, 187.

62 W H Schmidt, Einfühnung in das Alte Testament, Berlin 1982, 241.

63 Rudolph, $a w, 37$.

64 Schreiner, $a w, 41$; Oosterhoff, $a w, 192$ meen hier is sprake van mense soos onder andere regters en bestuurders.

65 Rudolph, $a w, 37$.

66 Thompson, $a w, 235$.

67 Thompson, $a w, 249$.

68 Schmidt, $a w, 241$; Oosterhoff, $a w, 218$. 
69 Rudolph, $a w, 61$; vergelyk Thompson, $a w, 297$ wat kies vir die tyd van Jojakim.

70 Schreiner, $a w, 63$; Oosterhoff, $a w, 273-276$.

$71 \quad$ Schreiner, $a w, 68$.

72 H L Bosman, "Egbreek en tradisie. 'n Historiese ondersoek van egbreukuitsprake in die Ou Testament, met besondere verwysing na die dekaloog", DTh proefskrif, Pretoria 1983, 225-226.

73 Thompson, $a w, 310$.

74 Thompson, $a w, 318$.

75 Schreiner, $a w, 73$.

76 Schmidt, a w, 241; R P Carroll, Jeremiah, London 1986, 357 meen egter dat die wysheidsgesegde nie noodwendig na Jojakim verwys nie, maar dat dit algemeen van aard is.

77 Thompson, $a w, 422$; Rudolph, $a w, 116$. 